\title{
Field bean inclusion in the diet of early-lactation dairy cows: Effects on performance and nutrient utilization
}

\author{
D. J. Johnston, ${ }^{1,2 *}$ K. Theodoridou, ${ }^{2}$ A. W. Gordon, ${ }^{3}$ T. Yan, ${ }^{1}$ W. C. McRoberts, ${ }^{3}$ and C. P. Ferris ${ }^{1}$ \\ ${ }^{1}$ Agri-Food and Biosciences Institute, Hillsborough, Co. Down, BT26 6DR, United Kingdom \\ ${ }^{2}$ Queens University Belfast, Co. Antrim, BT7 1NN, United Kingdom \\ ${ }^{3}$ Agri-Food and Biosciences Institute, Belfast, Co. Antrim, BT9 5PX, United Kingdom
}

\section{ABSTRACT}

The European livestock sector has a significant deficit of high-quality protein feed ingredients. Consequently there is interest in using locally grown protein grain crops to partially or completely replace imported protein feeds in dairy cow rations. Field bean (FB; Vicia faba) has been identified as a locally grown crop with significant potential. The current study was designed to examine the effects of FB on cow performance and nutrient utilization in the diet of early-lactation dairy cows, including high levels of FB (up to $8.4 \mathrm{~kg} /$ cow per day). The experiment used 72 dairy cows in a 3-treatment continuous design (from calving until wk 20 of lactation). All cows were given ad libitum access to a mixed ration comprising grass silage and concentrates [45:55 on a dry matter (DM) basis]. Concentrates offered contained either 0,349 , or $698 \mathrm{~g}$ of $\mathrm{FB} / \mathrm{kg}$ of concentrate (treatments FB0, FB-Low, and FB-High, respectively), with FB completely replacing soybean meal, rapeseed meal, maize gluten, and wheat in the concentrate for the FB-High treatment. Following completion of the 20-wk experiment, ration digestibility, nutrient utilization, and methane $\left(\mathrm{CH}_{4}\right)$ production were measured using 4 cows from each treatment. Neither silage DM intake, total DM intake, nor milk yield were affected by treatment. Cows on FB0 had a higher milk fat content than those on FB-High, and cows on FB0 and FB-Low had higher milk protein contents than did those on FB-High. Field bean inclusion increased the degree of saturation of milk fat produced. Milk fat yield, milk protein yield, and milk fat plus protein yield were higher with FB0 than with either FB-Low or FB-High. Treatment had no effect on the digestibility of DM, organic matter, nitrogen $(\mathrm{N})$, gross energy, or neutral detergent fiber, whereas digestibility of acid detergent fiber was higher with FB0 than with

Received February 19, 2019.

Accepted June 18, 2019.

*Corresponding author: djohnston35@qub.ac.uk
FB-High. Neither the efficiency of gross energy or N utilization, nor any of the $\mathrm{CH}_{4}$ production parameters examined, were affected by treatment. Similarly, none of the fertility or health parameters examined were affected by treatment. The reduction in milk fat observed may have been due to the higher starch content of the FB-High diet, and the reduction in milk protein may have been due to a deficit of methionine in the diet. It is likely that these issues could be overcome by changes in ration formulation, thus allowing FB to be included at the higher range without loss in performance.

Key words: dairy cattle, field bean (Vicia faba), milk production, nutrient utilization, methane production

\section{INTRODUCTION}

The increasing milk yield potential of dairy cows in many European countries has led to a requirement for more nutrient-dense diets. Increased nutrient density has often been achieved through the adoption of higherconcentrate feed levels, and this in turn has increased the demand for high-quality protein ingredients. However, European agriculture has a significant deficit of high-quality protein feedstuffs (Watson et al., 2017). This is a particular problem in the United Kingdom, driving considerable interest in increased use of locally grown protein ingredients (Wilkins and Jones, 2000). One protein crop of particular interest, especially in the cooler, wetter regions of the United Kingdom, is the field bean (FB; Vicia faba).

Although FB have a moderate CP content (280 g/ $\mathrm{kg}$ of $\mathrm{DM}$ ), they have a relatively high starch content (400 g/kg of DM; Ewing, 1997) and, as such, might appear to be ideal in ruminant diets. However, the inclusion of FB in ruminant diets is normally limited due to the perceived risk associated with antinutritional substances, including trypsin inhibitors, tannins, lectins, and protease inhibitors, which can reduce DM intake and animal performance (Dvořák et al., 2006). In addition, FB contain several phytoestrogens, some of which are known to have negative effects on reproductive performance (Zdunczyk et al., 2005), which has 
also contributed to the limited inclusion of FB in dairy cow diets.

The use of FB in dairy cow diets has been examined in several studies, with the findings sometimes conflicting. For example, although neither DM intake nor milk yield were affected by FB inclusion in studies by Ingalls and McKirdy (1974) and Johnston et al. (2019), Ramin et al. (2017) observed a reduction in milk yield with FB inclusion. In contrast, Puhakka et al. (2016) found both DM intake and milk yield to be reduced when rapeseed meal was replaced by FB.

These studies have demonstrated that in some circumstances FB can be included in dairy cow diets at levels between 4.7 and $5.0 \mathrm{~kg} / \mathrm{d}$ (Ingalls and McKirdy, 1974; Johnston et al., 2019) with no adverse effects on DM intake and milk production, but higher inclusion levels do not appear to have been examined previously. Given the high starch content of FB, which suggests that it could replace both conventional protein and energy components of the diet, the effects of higher FB inclusion levels need to be examined. In addition, as highlighted by Tufarelli et al. (2012), information on the effects of FB inclusion in the diet of dairy cows in early lactation, the period that encompasses the breeding season, is limited at present. This is important, given concerns about the presence of estrogenic compounds in $\mathrm{FB}$, although there is no evidence that dairy cow fertility is reduced when FB are offered. Consequently, the current study was designed to examine the effects on cow performance, nutrient utilization efficiency, and fertility when early-lactation dairy cows were offered diets containing higher levels of FB than examined previously. We hypothesized that these parameters would be unaffected by these higher levels of FB inclusion.

\section{MATERIALS AND METHODS}

This experiment was conducted at the Agri-Food and Biosciences Institute, Hillsborough, Northern Ireland (NI). All experimental procedures were conducted under an experimental license granted by the Department of Health, Social Services and Public Safety for NI, in accordance with the Animals (Scientific Procedures) Act 1986.

\section{Animals and Housing}

This continuous-design 20-wk experiment involved 72 Holstein-Friesian dairy cows, 33 primiparous and 39 multiparous; mean parity 2.07 (SD 1.19). During the 3 -wk period before calving, cows had ad libitum access to grass silage, while a dry-cow mineral and vitamin mix, along with calcined magnesite (Trouw Nutrition, Cheshire, UK), were mixed with the silage to achieve a target intake of $100 \mathrm{~g} /$ cow per day and $50 \mathrm{~g} / \mathrm{cow}$ per day, respectively. Cows were moved to a straw-bedded maternity pen approximately 24 to $48 \mathrm{~h}$ before calving, based on behavioral observations. Following calving (normally within $24 \mathrm{~h}$ ), cows were transferred to an experimental free-stall barn with solid concrete floors, where they had access to cubicles fitted with rubber mats, which were bedded with sawdust twice daily. The floor was scraped every $3 \mathrm{~h}$, using an automated slurry scraper system.

\section{Treatments}

The variety of FB (Vicia faba var. Fuego) used in the study was described by Flores et al. (2013) as having "colored flower, high standing ability, high yield potential, big seeds." Colored-flower varieties of FB have long been known to have higher tannin contents than white-flowered varieties (Newton and Hill, 1983), with Abdulla (2017) recently recording the tannin content of the Fuego variety as $6.1 \mathrm{mg} / \mathrm{g}$ of DM. This variety was chosen for use in this study because it has been successfully grown by local arable and livestock farmers in NI over several years. The study by Flores et al. (2013) also demonstrated that this variety could be successfully grown over wide areas of Europe, with this variety having been evaluated previously in a dairy cow study in Lithuania (Kudlinskienė et al., 2018). The beans offered within this study were grown in NI. The crop was sown during spring 2016, harvested on September 28, 2016 , and then dried at $80^{\circ} \mathrm{C}$ for approximately $2 \mathrm{~h}$ to achieve a moisture content of approximately $14 \%$.

Cows were randomly allocated to 1 of 3 treatments at calving (FB0, FB-Low, FB-High), with primiparous and multiparous cows allocated separately. A check was made to ensure that each treatment group remained balanced for parity, BW, and BCS at drying-off, and, in the case of multiparous cows, for previous lactation 305 -d milk yield and milk fat and protein contents.

Treatments differed in concentrate type offered (ingredient composition in Table 1). The concentrate offered with FB0 contained no FB, whereas concentrates offered with FB-Low and FB-High contained 349 and $698 \mathrm{~g}$ of FB per kilogram (fresh basis), respectively. The experimental concentrates (in the form of a meal) were mixed with grass silage (forage:concentrate ratio of 45:55 on a DM basis), together with $320 \mathrm{~g} / \mathrm{cow}$ per day of straw and $50 \mathrm{~g} / \mathrm{cow}$ per day of a rumen buffer (Acid Buf, Celtic Sea Minerals, Cork, Ireland; buffering capacity approximately $2.5 \times$ that of sodium bicarbonate), and offered in the form of a mixed ration. The grass silage component of the diet was produced from a primary growth (approximately $75 \%$ of cow feeding days) and a primary regrowth (approximately 25\% of 
cow feeding days) of perennial ryegrass (Lolium perenne)-based swards. The rations were prepared and offered daily at approximately $0900 \mathrm{~h}$ (at proportionally 1.07 of the previous day's intake), with uneaten ration removed the following day at approximately $0800 \mathrm{~h}$. Rations were prepared using a feeder wagon (Vari-Cut 12, Redrock, Armagh, NI). The total silage requirement for all 3 treatments was initially mixed for approximately $4 \mathrm{~min}$ and then deposited on a clean covered concrete yard. Silage for each individual treatment was then removed from this "pile" and returned to the feeder wagon. The appropriate quantities of concentrate, straw, and buffer were added to the mix, and mixing continued for another $6 \mathrm{~min}$. The rations were then transferred from the wagon to a series of feedboxes mounted on weigh scales, with cows accessing feed in these boxes via an electronic identification system, enabling individual cow intakes to be recorded daily (Controlling and Recording Feed Intake, BioControl, Rakkestad, Norway). Cows had free access to fresh water at all times. In addition, all cows were offered 1.0 $\mathrm{kg}$ per day of soy hulls via an in-parlor feeder during milking ( $0.5 \mathrm{~kg}$ at each milking). Cows remained on the experiment until d 140 of lactation.

\section{Cow Measurements}

During the experiment cows were milked twice daily (between 0500 and $0700 \mathrm{~h}$, and between 1500 and 1700 h) using a 50-point rotary milking parlor (BouMatic, Madison, WI), with milk yields recorded automatically at each milking and a total daily milk yield for each cow for each 24-h period calculated. Milk samples were taken during 2 consecutive milkings each week, a preservative tablet was added (Broad Spectrum Microtabs II, D and F Control Systems, Advanced Instruments Inc., Norwood, MA), and samples were stored at $4^{\circ} \mathrm{C}$ until analyzed. Samples were analyzed for fat, protein, and lactose using an infrared milk analyzer (Milkoscan model FT+; Foss Electric, Hillerod, Denmark), and a weighted concentration of each constituent was determined for the 24-h sampling period. A single milk sample was collected for progesterone analysis from each cow on 2 occasions each week (Monday and Thursday p.m.) until $60 \mathrm{~d}$ postpartum. Samples were preserved and stored as above, for a maximum of $3 \mathrm{wk}$, with progesterone concentrations subsequently determined using a competitive ELISA kit (Ridgeway Science Ltd., Gloucestershire, UK). In addition, at 10 and $20 \mathrm{wk}$ postcalving ( $\pm 1 \mathrm{wk})$ a milk sample was taken in proportion to yield during 2 successive milkings (a.m. and p.m.), the 2 samples bulked, and the bulked sample frozen at $-20^{\circ} \mathrm{C}$. These samples were subsequently analyzed for milk FA, as follows: milk fat was extracted from 1.0
Table 1. Ingredient composition $(\mathrm{g} / \mathrm{kg})$ of concentrates offered during the experiment

\begin{tabular}{|c|c|c|c|}
\hline \multirow[b]{2}{*}{ Ingredient } & \multicolumn{3}{|c|}{ Treatment } \\
\hline & FB0 & FB-Low & FB-High \\
\hline Field beans (FB) & 0 & 349 & 698 \\
\hline Soybean meal & 170 & 85 & 0 \\
\hline Rapeseed meal & 150 & 75 & 0 \\
\hline Maize gluten feed & 74 & 37 & 0 \\
\hline Maize meal & 245 & 178 & 110 \\
\hline Wheat & 174 & 87 & 0 \\
\hline Soy hulls (toasted) & 140 & 139 & 140 \\
\hline Molaferm $^{1}$ & 25 & 25 & 25 \\
\hline Calcined magnesite & 6 & 6 & 6 \\
\hline Limestone $\left(\mathrm{CaCO}_{3}\right)$ & 7 & 6 & 5 \\
\hline Dicalcium phosphate & 0 & 5 & 10 \\
\hline Salt & 6 & 4 & 2 \\
\hline Mineral and vitamin premix ${ }^{2}$ & 4 & 4 & 4 \\
\hline
\end{tabular}

${ }^{1}$ United Molasses, Belfast, UK.

${ }^{2}$ Devenish Nutrition, Belfast, UK. Contains a minimum of (per $\mathrm{kg}$ ) vitamin A retinyl acetate $(2,500,000 \mathrm{IU})$, vitamin $\mathrm{D}_{3}$ cholecalciferol (500,000 IU), vitamin $\mathrm{E}$ alpha tocopherol $(18,750 \mathrm{mg})$, vitamin $\mathrm{B}_{12}$ $(7,500 \mu \mathrm{g} / \mu \mathrm{g})$, biotin $(500 \mathrm{mg})$, iodine from calcium iodate anhydrous $(1,875 \mathrm{mg})$, selenium from sodium selenite $(150 \mathrm{mg})$, selenium from organic form of selenized yeast inactivated $(25 \mathrm{mg})$, cobalt from coated granulated cobalt carbonate $(40 \mathrm{mg})$, manganese from manganese(II) oxide $(12,500 \mathrm{mg})$, copper from copper(II) sulfate pentahydrate $(5,625$ $\mathrm{mg}$ ), copper from copper(II) chelate of amino acid hydrate $(1,875 \mathrm{mg})$, zinc from zinc oxide $(18,750 \mathrm{mg})$, and zinc from zinc chelate of amino acid hydrate $(6,250 \mathrm{mg})$.

$\mathrm{mL}$ of homogenized milk using a chloroform methanol extraction method (Bligh and Dyer, 1959), and FAME prepared. The FA composition was determined using GLC, with an aliquot $(1.0 \mu \mathrm{L})$ of the FAME extract injected onto a CP Sil88 capillary column $(100 \mathrm{~m} \times$ 0.25 -mm internal diameter $\times 0.2-\mu \mathrm{m}$ film thickness) in a, Agilent 7800 gas chromatograph (both from Agilent Technologies, Santa Clara, CA), equipped with a temperature programmable injector operated in the split mode and a flame ionization detector. The oven was initially held at $50^{\circ} \mathrm{C}$ for $4 \mathrm{~min}$, then increased at $8^{\circ} \mathrm{C} /$ min to $110^{\circ} \mathrm{C}$, then at $5^{\circ} \mathrm{C} / \mathrm{min}$ to $170^{\circ} \mathrm{C}$ (hold time 10 min), and finally at $2^{\circ} \mathrm{C} / \mathrm{min}$ to $225^{\circ} \mathrm{C}$ (hold time 30 min). Fatty acids were identified by their retention time with reference to commercially available FA standards (37 Supelco FAME mix) and individual standards for those not in the mix (Sigma-Aldrich Co. Ltd., Gillingham, UK), and were quantified using C13 FAME as an internal standard.

Body weight was recorded twice daily (immediately after each milking) using an automated weighbridge, and a mean weekly BW for each cow was determined. The BCS of each cow was estimated fortnightly according to Edmonson et al. (1989) by a trained technician. Fecal scores were assessed at 6 and 12 wk post-calving ( \pm 1 wk) using a scale of 1 to 5 , as described by IrelandPerry and Stallings (1993). Blood samples were collected from the tail of each cow before feeding, at 2 , 
$4,6,8,10$, and $14 \mathrm{wk}( \pm 3 \mathrm{~d})$ post-calving. Samples were collected into evacuated tubes (Becton Dickinson, Oxford, UK), which were coated with either a clot activator or fluoride oxalate. The blood samples were centrifuged $\left(1,800 \times g\right.$ at $17^{\circ} \mathrm{C}$ for $\left.30 \mathrm{~min}\right)$ to obtain serum (tubes with clot activator) or plasma (fluoride oxalate tubes), which were separated and stored at $-20^{\circ} \mathrm{C}$ until analyzed. Plasma was analyzed for glucose concentrations, whereas serum was analyzed for BHB, nonesterified fatty acids (NEFA), and urea concentrations. Plasma glucose concentrations were determined using the hexokinase method (Roche Diagnostics Ltd., Burgess Hill, UK), and serum biochemistry analysis was carried out on a Randox Imola chemistry analyzer system, using Randox reagent kits (Randox Laboratories, Crumlin, UK).

A clinical examination of vaginal mucus was conducted at 2, 4, and 6 wk postpartum, as an indicator of immune status. The methodology and scoring system used was as described by Little et al. (2017), with the combined results expressed on a scale of 0 to 5 . In the current study, scores were subsequently grouped into 3 categories for analysis $(0,1, \geq 2)$.

\section{Nutrient Utilization}

On completion of the 20-wk feeding study, 4 cows from each treatment were selected for use in a nutrientutilization study, with the cows selected from each treatment group balanced for daily milk yield and BW. Cows were transferred in pairs from the main experimental group into a digestibility unit, with pairs transferred at approximately $0900 \mathrm{~h}$ on Monday or Thursday of each week. The first pair transferred comprised cows from treatments FB0 and FB-Low; the second, cows from treatments FB-High and FB0; and the third, cows from FB-Low and FB-High. This pattern was repeated for the remaining 3 pairs. Cows were tied by the neck in individual stalls fitted with a rubber mat, and continued to be offered their experimental rations via a feedbox located at the front of each stall. Rations were offered ad libitum daily at $0900 \mathrm{~h}$, at proportionally 1.07 of the previous d intake, and uneaten ration was removed the following day at $0800 \mathrm{~h}$. Soy hulls were offered $(0.5 \mathrm{~kg}$ at each milking) via a plastic feed bucket, which was placed within the feedboxes during milking (at 0630 and $1630 \mathrm{~h}$ ). Cows had access to fresh water at all times via a drinker located within each stall.

Measurements of nutrient utilization commenced 24 $\mathrm{h}$ after cows were placed in the digestibility unit and comprised a 6 -d feeding period, followed $48 \mathrm{~h}$ later by a 6 -d total feces and urine collection period. Following collection of feces and urine on $\mathrm{d} 3$ of the 6 - $\mathrm{d}$ collection period, each pair of cows was transferred into 2 indirect open-circuit respiration chambers for measurement of $\mathrm{CH}_{4}$ production, with each chamber used twice with each treatment, to remove any possible chamber effects. Cows remained in the chambers for $72 \mathrm{~h}$, with measurements of $\mathrm{CH}_{4}$ and $\mathrm{CO}_{2}$ production recorded during the final 48 -h period used in the subsequent analysis. The milking routine, milk sampling, milk analysis, feces and urine collection methodologies, sample management throughout the 6-d collection period, specifications of the respiration chambers, details of measurements of $\mathrm{CH}_{4}$ production, laboratory analysis processes of all feed, milk, urine, and feces, have been described in our previous work (Johnston et al., 2019). In the present study, a mean $\mathrm{CH}_{4}$ recovery rate of $98.5 \%$ was recorded.

\section{Feed Analysis}

Samples of grass silage were taken daily throughout the experiment and dried at $85^{\circ} \mathrm{C}$ for $24 \mathrm{~h}$ to determine oven DM (ODM) content. Subsamples of the dried milled silages were taken 3 times weekly and bulked for every $14 \mathrm{~d}$, with the bulked sample analyzed for NDF, ADF, and ash concentrations. A fresh sample of grass silage was taken weekly and analyzed for concentrations of $\mathrm{N}$, ammonia-N, lactic acid, acetic acid, ethanol, propanol, and gross energy (GE), and for $\mathrm{pH}$, whereas ME content was predicted using near-infrared reflectance spectroscopy, as described by Park et al. (1998). A sample of each experimental concentrate offered (FB0, FB-Low, and FB-High) was taken weekly, bulked for each 2-wk period, and subsequently dried at $85^{\circ} \mathrm{C}$ for $24 \mathrm{~h}$ to determine ODM content. Additional samples of each experimental concentrate were taken weekly, bulked for each 2 -wk period, dried at $60^{\circ} \mathrm{C}$ for $48 \mathrm{~h}$, and analyzed for N, NDF, ADF, ash, GE, and starch concentrations. These latter samples were further bulked for each 4-wk period and analyzed using the procedure developed by Licitra et al. (1996) for ADIN and NDIN. Acid detergent insoluble protein (ADIP) and neutral detergent insoluble protein (NDIP) were calculated as $\mathrm{ADIP}=6.25 \times \mathrm{ADIN}$ and $\mathrm{NIDP}=6.25$ $\times$ NDIN, respectively.

Straw and soy hulls offered were sampled weekly, the samples bulked every $4 \mathrm{wk}$, and the bulked samples dried at $85^{\circ} \mathrm{C}$ for $24 \mathrm{~h}$ to determine ODM content. Dried samples were subsequently analyzed for N, GE, ADF, NDF, and ash content. Laboratory analyses of all feed samples were undertaken as described previously by Purcell et al. (2016).

\section{Statistical Analysis}

Two primiparous cows from treatment FB-Low did not complete the study due to lameness and very low 
milk yield, respectively. Mean weekly data for DMI, milk production, milk composition, milk constituent yields, and BW over the 20-wk experimental period were analyzed using REML repeated measures analysis (autoregressive order 1). The mixed model used included the following terms as fixed effects: Parity (1, $2,3,>3)+\mathrm{Wk}(1-20$, as the repeated-measures time factor) + FB inclusion level (FB0, FB-Low, FB-High) $+\mathrm{Wk} \times \mathrm{FB}$ inclusion level, and cow was fitted as a random effect. Locomotion score and BCS data were analyzed using the same model, except that fortnightly data were used as the repeated-measures time factor. Milk FA and blood metabolites were analyzed using a similar model, except that for the former, sampling week (10 and 20 post-calving) was used as the repeated-measure time factor, whereas with the latter, sampling week $(2,4,6,8,10$, and 14-post calving) was used as the repeated-measures time factor. Continuous BW, BCS, and fertility data were analyzed by ANOVA, with parity included as a covariate. For each continuous variable, polynomial contrasts of order 1 were fitted to the treatment effects to test the data for linear effects associated with increasing FB level. Binomial fertility and health data were analyzed via generalized linear model regression analysis using the binomial distribution with a logit link function. The model included treatment as a term, with parity included as a covariate in the case of mastitis incidence. Mucus scores of 2 and 3 were combined into a single category (2-3), yielding categories of 0,1 , and $2-3$ for analysis. These categorical data were analyzed using a generalized linear mixed model (ordinal logistic regression) with random effects (proportional odds model). The factorial arrangement of treatment (FB0, FB-Low, or FB-High) and sampling week (wk 6 and 12 for feces scores; wk 2, 4, and 6 for mucus scores) were fitted as fixed effects, and cow was fitted as a random effect. Significance was identified using chi-squared. Mean nutrient utilization data over the 6-d measurement period, and mean $\mathrm{CH}_{4}$ production data over the 2-d measurement period, were analyzed using ANOVA. All data were analyzed using GenStat (Release 18.1; VSN International Ltd., Oxford, UK).

\section{RESULTS}

The silage offered had ODM, CP, and ME contents of $293 \mathrm{~g} / \mathrm{kg}, 145 \mathrm{~g} / \mathrm{kg}$ of DM, and $11.0 \mathrm{MJ} / \mathrm{kg}$ of DM, respectively (Table 2). The 3 experimental concentrates had similar CP contents (mean, $223 \mathrm{~g} / \mathrm{kg}$ of DM), and the starch contents of FB0, FB-Low, and FB-High concentrates were 291, 313, and $338 \mathrm{~g} / \mathrm{kg}$ of DM, respectively. However, the NDIP of the concentrates decreased, being 112,98 , and $90 \mathrm{~g} / \mathrm{kg}$ of $\mathrm{DM}$ for FB0, FB-Low, and FB-High, respectively, and the respective values for ADIP were 28.5, 21.6, and 16.6. The straw offered had CP, ADF, NDF, and ash contents of 46 (SD $\pm 11.2), 501( \pm 9.6), 866( \pm 20.7)$, and $57( \pm 13.2) \mathrm{g} / \mathrm{kg}$ of DM, and a GE content of $18.5( \pm 0.23) \mathrm{MJ} / \mathrm{kg}$ of DM. The respective values for the soy hulls offered were $111( \pm 4.3), 492( \pm 11.3), 685( \pm 29.4), 53( \pm 1.1) \mathrm{g} / \mathrm{kg}$ of DM, and $17.5( \pm 0.06) \mathrm{MJ} / \mathrm{kg}$ of DM, with a starch content of $13.9( \pm 7.84) \mathrm{g} / \mathrm{kg}$ of DM.

Neither total DMI nor milk yield were affected by treatment $(P>0.05$; Table 3$)$. Silage DMI was estimated as $9.7,9.6$, and $9.8 \mathrm{~kg} / \mathrm{d}$ for FB0, FB-Low, and FB-High, respectively (based on ration formulation), and the respective values for concentrates were 11.8, 11.7 , and $12.2 \mathrm{~kg} / \mathrm{d}$. Cows on FB0 had higher milk fat content than those on FB-High $(P=0.031)$, whereas cows on FB0 and FB-Low had higher milk protein content than those on FB-High $(P<0.001)$. Milk lactose content was not affected by treatment $(P>0.05)$. Milk fat yield $(P<0.001)$, milk protein yield $(P=0.035)$, and milk fat plus protein yield $(P=0.007)$ were higher with FB0 than with either FB-Low or FB-High. All of these DMI and milk production parameters varied with time post-calving $(P<0.001$; see Figure 1 for DMI and Figure 2 for milk yield), but we found no treatment $\times$ time interaction for any of these parameters. Milk fat, protein, and lactose concentrations showed linear decrease with FB inclusion $(P=0.012, P<0.001$, and $P=0.046$, respectively), as did milk fat yield $(P=$ $0.002)$, milk protein yield $(P=0.020)$, and milk fat plus protein yield $(P=0.006)$.

The total concentration of SFA in milk fat was lower with FB0 than with either FB-Low or FB-High $(P=$ $0.028)$, but the reverse was true for the total concentration of MUFA $(P=0.016$; Table 3$)$. Treatment had no effect on the total PUFA content of milk fat $(P>0.05)$. Concentrations of $\mathrm{C} 18: 0(P=0.002), \mathrm{C} 18: 1$ cis $-9(P=$ $0.022)$, and $\mathrm{C} 18: 2$ cis-9,trans-11 $(P<0.001)$ decreased with increasing FB inclusion; however, concentrations of C16:0 $(P<0.001)$ and $\mathrm{C} 18: 3 \mathrm{n}-3(P<0.006)$ increased. Concentrations of $\mathrm{C} 14: 0$ and $\mathrm{C} 18: 2$ were not affected by treatment $(P>0.05)$. Although total PUFA concentrations $(P<0.001)$ and concentrations of C16:0 $(P=0.002), \mathrm{C} 18: 0(P<0.001), \mathrm{C} 18: 2(P<0.001)$, and C18:3n-3 $(P<0.001)$ differed between the 2 sampling periods (time) with the exception of the latter $(P<$ $0.001)$, we found no treatment $\times$ time interactions for any of the FA recorded $(P>0.05)$. Total MUFA concentrations $(P=0.016)$ and concentrations of C18:0 $(P<0.001), \mathrm{C} 18: 1$ cis-9 $(P=0.020)$, and CLA $(P<$ $0.001)$ showed a linear decrease with FB inclusion, but concentrations of C16:0 $(P<0.001)$ and $\mathrm{C} 18: 3 \mathrm{n}-3(P=$ 0.002 ) showed the reverse trend.

Although average BCS was unaffected by treatment $(P<0.05)$, end-of-study BCS tended to increase with 


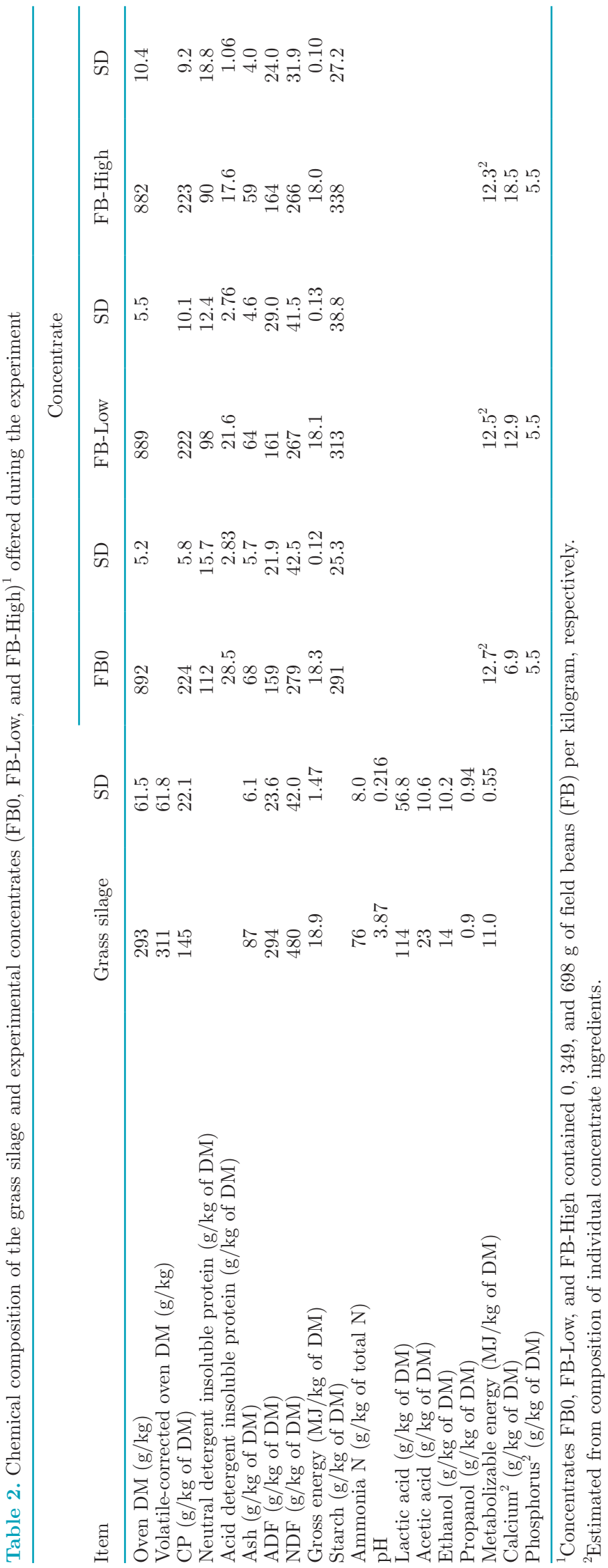

increasing levels of FB inclusion $(P=0.054$; Table 4), with this overall linear effect significant $(P=0.020)$. None of the BW parameters examined (average BW, end-of-study BW, nadir BW, BW loss to nadir, and days to nadir $\mathrm{BW})$ were affected by treatment $(P>$ 0.05). Both BCS $(P=0.046)$ and BW $(P<0.001)$ varied with time (Figures 3 and 4 , respectively), but we found no treatment $\times$ time interactions for either $(P<0.05)$. Plasma glucose and BHB concentrations were unaffected by treatment $(P>0.05)$, although both increased with time post-calving (Figure $5 \mathrm{a}, P$ $=0.010 ;$ Figure 5b, $P=0.002$, respectively). Plasma NEFA concentrations were significantly higher with FB0 than with FB-High $(P=0.022)$; however, plasma urea concentrations followed the reverse trend $(P<$ 0.001). Plasma NEFA concentrations decreased with time post-calving (Figure 5c, $P<0.001$ ), but plasma urea concentrations increased (Figure 5d, $P<0.001$ ). We detected no treatment $\times$ time interactions for any of the blood metabolites examined $(P>0.05)$. With increasing FB inclusion levels, analysis revealed a tendency for linear decrease in plasma glucose concentrations $(P=0.067)$, whereas plasma NEFA concentrations showed a linear decrease $(P=0.005)$. Plasma urea levels increased linearly with FB inclusion $(P<$ $0.001)$.

Fecal scores differed between wk 6 and 12 post-calving (overall SEM $=0.048, P=0.012$ ), but treatment had no effect on mean fecal scores (probability of having a score of 1,2 , or $\geq 3: 0.08,0.47$, and 0.45 for FB0; 0.05, 0.42 , and 0.53 for FB-Low; 0.07, 0.45, and 0.48 for FBHigh: overall SEM $=0.061, P=0.878)$. We found no interaction between treatment and measurement period $(\mathrm{SEM}=0.084, P=0.783)$. The digestibility of ADF decreased $(P=0.035$ : linear, $P=0.013)$ from FB0 to FB-High, but none of the other digestibility coefficients were affected by FB inclusion level (Table 5). Neither total $\mathrm{N}$ intake, digestible $\mathrm{N}$ intake, $\mathrm{N}$ output in feces, urine, manure, or milk, nor any of the $\mathrm{N}$ utilization coefficients examined were affected by treatment $(P>$ 0.05 ; Table 6). Treatment had no effect $(P>0.05)$ on GE intake, digestible energy (DE) intake, ME intake, energy output in feces, urine, $\mathrm{CH}_{4}$, heat, or milk, or any of the energy utilization coefficients examined (Table 7). Total $\mathrm{CH}_{4}$ production, $\mathrm{CH}_{4}$ as a proportion of DMI, OM intake, and milk production were unaffected by treatment $(P>0.05$; Table 7$)$. Similarly, $\mathrm{CH}_{4}-\mathrm{E}$, as a proportion of GE or ME intake, was unaffected by treatment $(P>0.05)$. There was a linear trend for ME/GE $(P=0.071)$ to decrease with increasing FB inclusion in the diet.

Vaginal mucus scores decreased with week $(2,4$, and 6 ) post-calving (overall SEM $=0.042, P<0.001$ ), but treatment had no effect on mean mucus scores (prob- 
FIELD BEAN INCLUSION LEVELS IN DAIRY COW DIETS

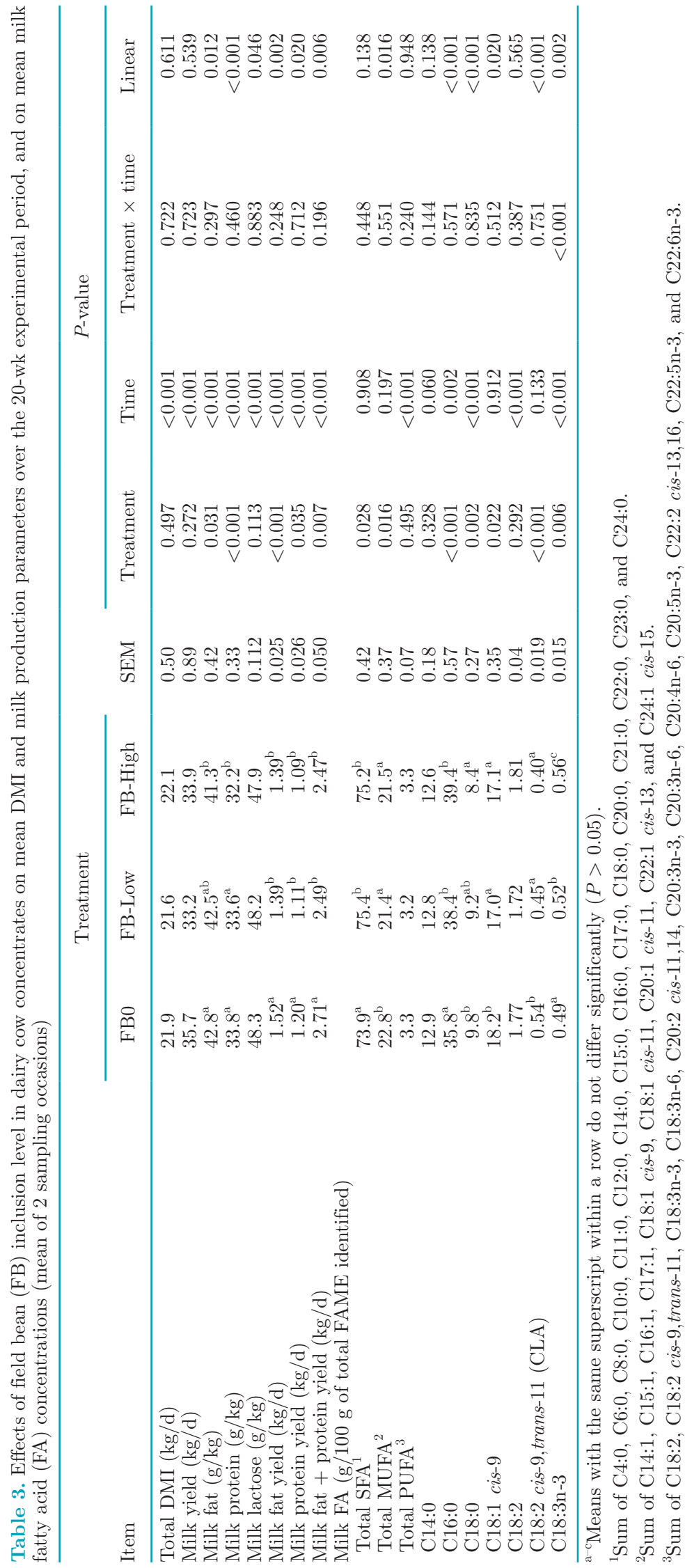


ability of having a score of 0,1 , or $2-3$ : $0.70,0.13$, and 0.17 for FB0; $0.71,0.13$, and 0.16 for FB-Low; $0.67,0.16$, and 0.17 for FB-High; overall SEM $=0.047$, $P=0.97)$. Analysis revealed no interaction between treatment and measurement week $(\mathrm{SEM}=0.072, P=$ $0.476)$. Treatment had no effect on the proportion of cows showing commencement of luteal activity before d 42 post-calving, days to commencement of luteal activity, or peak progesterone content at commencement of luteal activity $(P>0.05$; Table 8$)$. Treatment did not affect conception to first service, conception to first and second service, days to conception, or the proportion of cows pregnant at the end of the breeding season $(P$ $>0.05$ ). The proportion of cows with at least one incident of digestive upset, mastitis, or lameness, as well as mean locomotion score, were unaffected by treatment (Table $8 ; P>0.05$ ).

\section{DISCUSSION}

Average daily FB intakes for FB-Low and FB-High were estimated as 4.1 and $8.4 \mathrm{~kg} /$ cow, respectively, with the latter substantially higher than FB intake levels used in any previous study. At the maximum inclu- sion level adopted (FB-High, $698 \mathrm{~g}$ of FB per kilogram of concentrate), FB replaced all of the soybean meal, rapeseed meal, maize gluten feed, and wheat in the concentrate, compared with the control treatment (FB0). Although it was not possible to achieve a common starch level with each of the concentrates (291, 309, and $338 \mathrm{~g}$ per kilogram of DM for FB0, FB-Low, and FB-High concentrates, respectively), all had a similar $\mathrm{CP}$ content, resulting in a total diet $\mathrm{CP}$ content of 180 $\mathrm{g}$ per kilogram of DM across the 3 diets. This total diet $\mathrm{CP}$ content was somewhat higher than planned, yet it remains typical of many grass silage-based diets offered in the United Kingdom.

\section{Cow Performance}

The potential negative effects of antinutritional factors within FB on DM intake are often cited by nutritionists as a reason for low inclusion levels in dairy cow diets. In addition, preference trials (Hutson and van Mourik, 1981) have suggested that FB may be unpalatable. However, the current study clearly demonstrated that FB intakes of up to $8.4 \mathrm{~kg} / \mathrm{cow}$ per day had no negative effects on DM intakes. This is in agreement

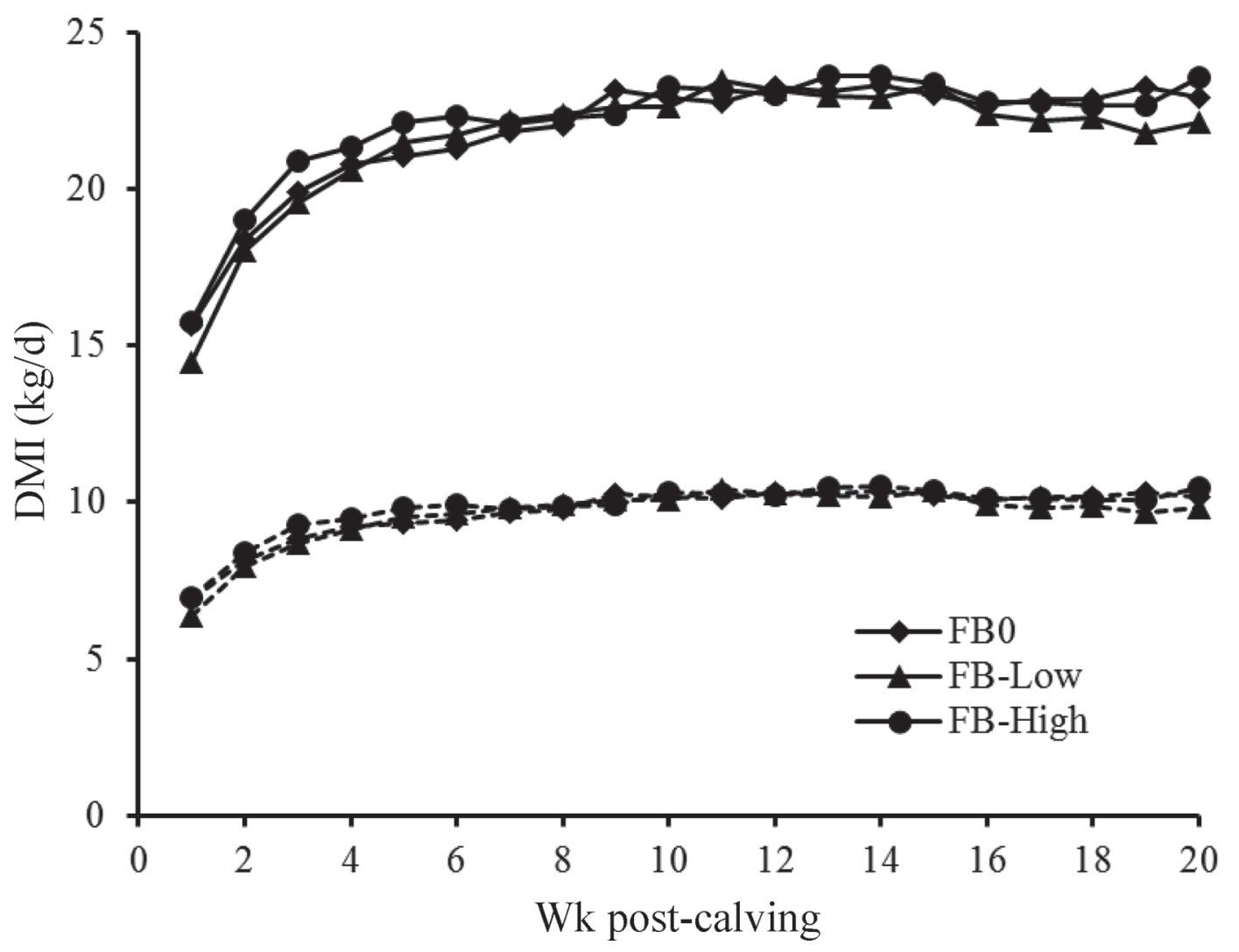

Figure 1. Silage DMI (dashed lines) and total DMI (solid lines) responses of dairy cows over the first 20 wk of lactation, to concentrates containing a range of field bean (FB) inclusion levels (FB0, FB-Low, or FB-High). Silage DMI: SEM $=0.22$; treatment $P=0.497$; time $P<$ 0.001 ; treatment $\times$ time $P=0.722$. Total DMI: SEM $=0.50$; treatment $P=0.497$; time $P<0.001$; treatment $\times$ time $P=0.722$. 


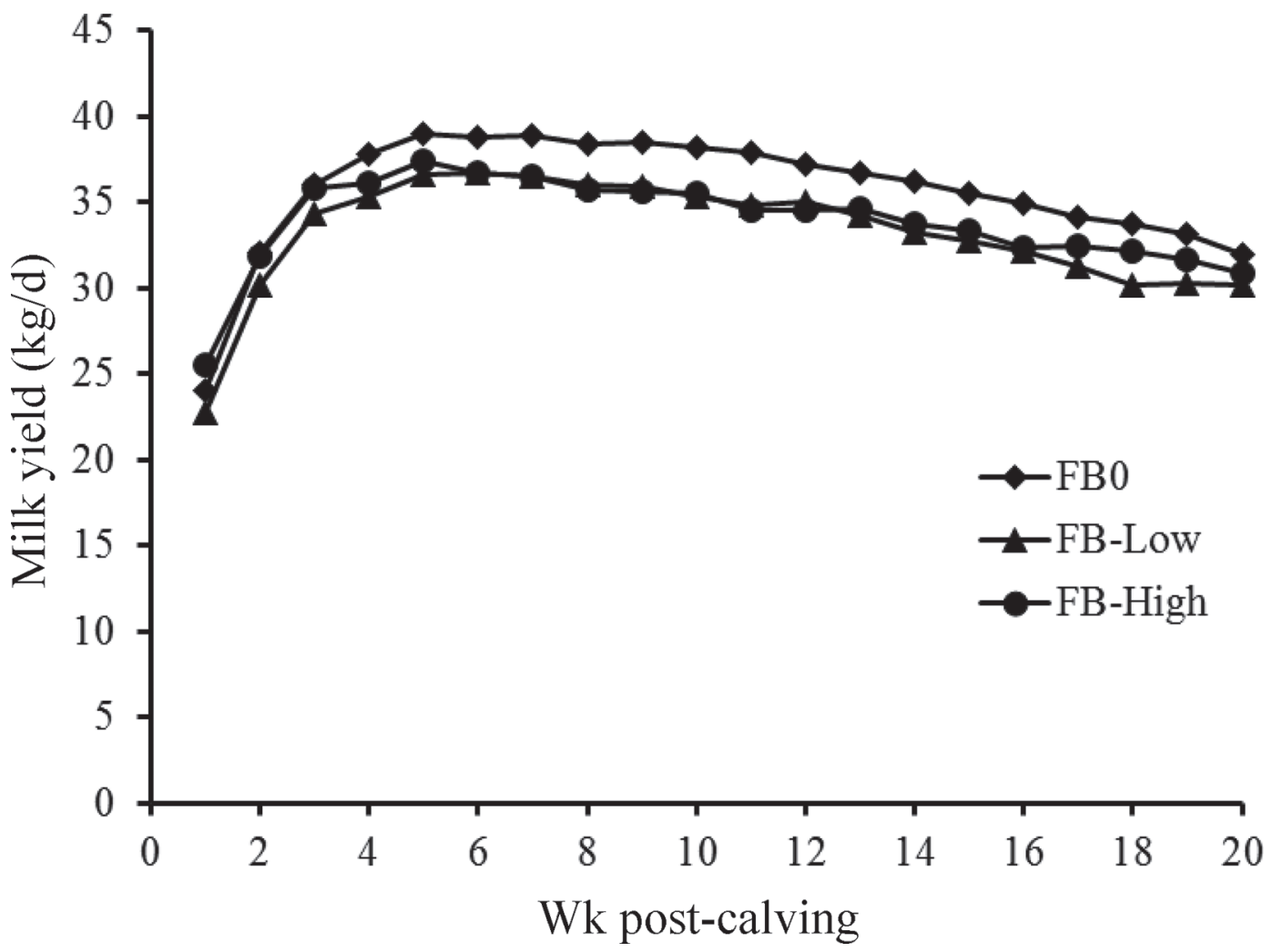

Figure 2. Milk yield response of dairy cows to concentrates containing a range of field bean (FB) inclusion levels (FB0, FB-Low, or FB-High) over the first 20 wk of lactation. SEM $=0.89$; treatment $P=0.272$; time $P<0.001$; treatment $\times$ time $P=0.723$.

with most published studies (Ingalls and McKirdy, 1974; Tufarelli et al., 2012; Ramin et al., 2017; Johnston et al., 2019), albeit the maximum daily FB intake in these studies was $5.0 \mathrm{~kg} / \mathrm{cow}$ per day, but the diets offered and concentrate feeding strategies adopted also differed considerably from those in the current study. In contrast, Puhakka et al. (2016) found intakes to be reduced when FB replaced rapeseed meal in dairy cow diets. Those authors suggested that this may have been due to a reduction in NDF digestibility, a poorer amino acid profile with FB, and a "pull effect" caused by the higher milk yield with the rapeseed meal treatment. Despite reductions in ADF digestibility with FB inclusion in the current study, this had no effect on DMI.

In common with DMI, milk yield was unaffected by FB inclusion. However, the reduction in both milk

Table 4. Effects of field bean (FB) inclusion level in dairy cow concentrates on BCS, BW, and plasma metabolite concentrations

\begin{tabular}{|c|c|c|c|c|c|c|c|c|}
\hline Item & \multicolumn{3}{|c|}{ Treatment } & SEM & \multicolumn{4}{|c|}{$P$-value } \\
\hline Average BCS & 2.49 & 2.53 & 2.51 & 0.024 & 0.259 & 0.046 & 0.248 & 0.371 \\
\hline Average BW (kg) & 598 & 600 & 599 & 8.0 & 0.899 & $<0.001$ & 0.760 & 0.646 \\
\hline End-of-study BW (kg) & 614 & 621 & 617 & 9.6 & 0.870 & & & 0.779 \\
\hline Nadir BW (kg) & 570 & 565 & 569 & 8.1 & 0.902 & & & 0.963 \\
\hline \multicolumn{9}{|l|}{ Plasma metabolites } \\
\hline Glucose (mmol/L) & 3.81 & 3.73 & 3.71 & 0.036 & 0.153 & 0.010 & 0.954 & 0.067 \\
\hline $\mathrm{BHB}(\mathrm{mmol} / \mathrm{L})$ & 0.51 & 0.51 & 0.48 & 0.018 & 0.419 & 0.002 & 0.123 & 0.206 \\
\hline $\mathrm{NEFA}^{1}(\mathrm{mEq} / \mathrm{L})$ & $0.43^{\mathrm{a}}$ & $0.39^{\mathrm{ab}}$ & $0.36^{\mathrm{b}}$ & 0.020 & 0.022 & $<0.001$ & 0.633 & 0.005 \\
\hline Urea $(\mathrm{mmol} / \mathrm{L})$ & $4.63^{\mathrm{a}}$ & $5.28^{\mathrm{b}}$ & $5.79^{\mathrm{c}}$ & 0.103 & $<0.001$ & $<0.001$ & 0.567 & $<0.001$ \\
\hline
\end{tabular}

${ }^{\mathrm{a}-\mathrm{c}}$ Means with the same superscript within a row do not differ significantly $(P>0.05)$.

${ }^{1} \mathrm{NEFA}=$ nonesterified fatty acids. 
fat and milk protein concentrations with FB inclusion meant that yields of fat, protein, and fat plus protein were lower with both FB-Low and FB-High, compared with the FB0 treatment. Literature evidence concerning the effects of $\mathrm{FB}$ inclusion on milk production and milk composition is inconsistent. For example, both $\mathrm{Pu}-$ hakka et al. (2016) and Ramin et al. (2017), in studies involving maximum FB intakes of 3.7 and $2.6 \mathrm{~kg}$ of DM per day, respectively, observed reductions in milk yield when rapeseed meal was replaced by FB. Milk protein content was reduced in the former study, but milk fat content was unaffected by FB inclusion in either study. In contrast, at an FB intake level of $4.7 \mathrm{~kg} / \mathrm{d}$ (Johnston et al., 2019), neither milk yield nor milk fat content were affected by FB inclusion level, and milk protein content tended to decrease $(P=0.08)$. In several onfarm studies conducted in Italy (Comellini et al., 2009; Volpelli et al., 2010; Tufarelli et al., 2012; Volpelli et al., 2012), the inclusion of FB in dairy cow diets had no effect on either milk yield or milk fat and protein content, although in a further study (Mordenti et al., 2007) milk yield was reduced but milk fat content was increased with FB inclusion. However, FB inclusion levels in these studies were low, normally less than 2.0 $\mathrm{kg} /$ cow per day.
Energy intake is a key driver of milk protein content, yet the reduction in milk protein content with the FB-Low treatment is unlikely to be driven by energy supply, given the similar intakes across all treatments and the absence of treatment effects on any of the BW or BCS score parameters. Indeed, plasma NEFA concentrations decreased with FB inclusion; however, there was a trend for end-of-study BCS to increase with FB inclusion, suggesting an improved energy balance with FB-High. Rather, it is more likely that this reduction was caused by a deficit of specific amino acids. For example, FB is lower in both lysine and methionine than are soybean meal or rapeseed meal (Ewing, 1997), with both of these amino acids important for milk protein synthesis (Schwab et al., 1976). When the rations were evaluated using Feed into Milk, the UK dairy cow rationing system (Thomas, 2004), lysine supply relative to requirements were "adequate" for all 3 treatments, whereas for methionine the FB0 ration was classified as "borderline," with both the FB-Low and FB-High rations classified as "poor." When Puhakka et al. (2016) replaced rapeseed meal with $\mathrm{FB}$, total concentrations of essential amino acids and plasma concentrations of lysine and methionine were reduced; these authors suggested that this was likely partly responsible for the

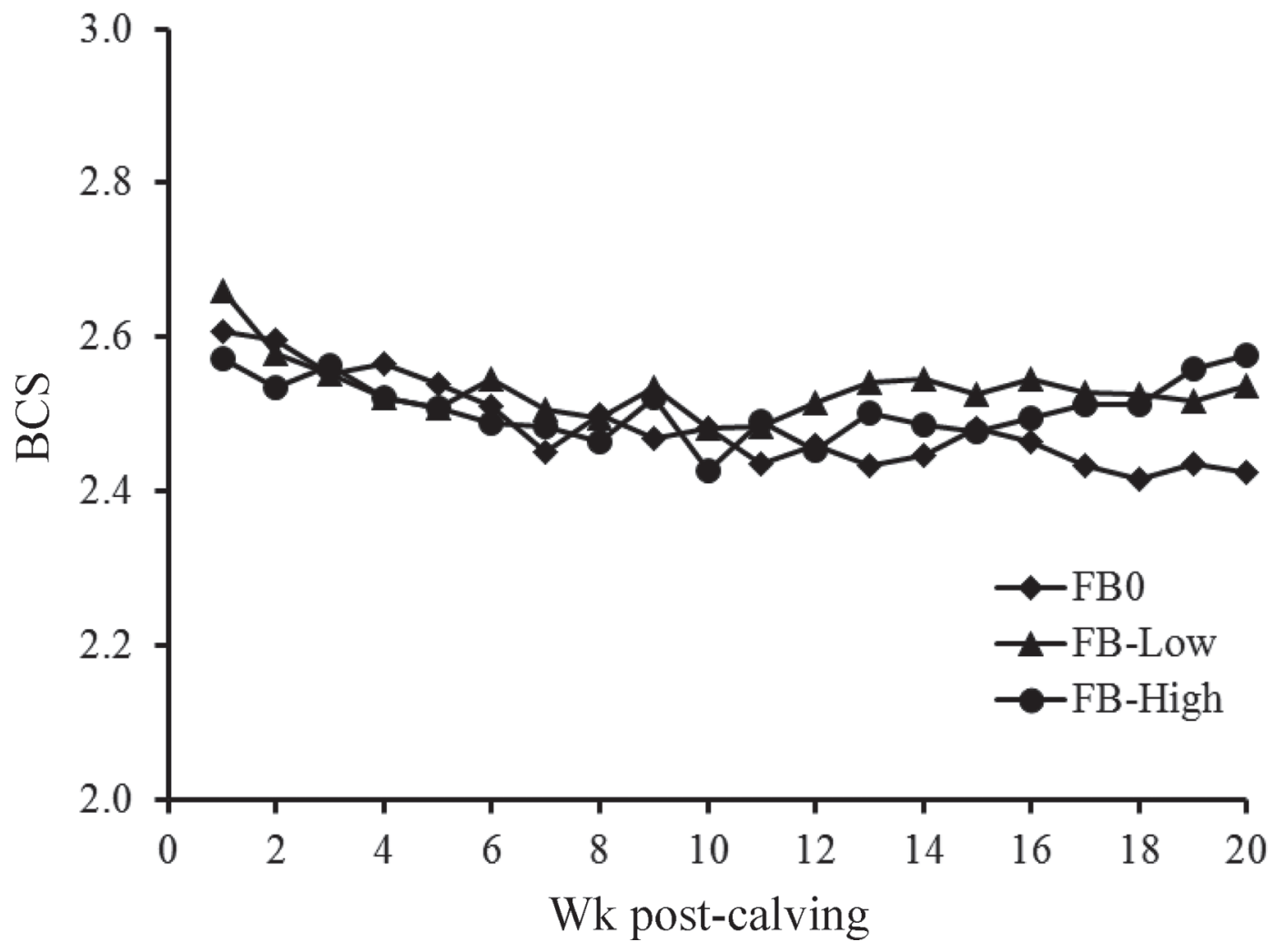

Figure 3. Body condition score (BCS) response of dairy cows to concentrates containing a range of field bean (FB) inclusion levels (FB0, FB-Low, or FB-High) over the first 20 wk of lactation. SEM $=0.024$; treatment $P=0.259$; time $P<0.046$; treatment $\times$ time $P=0.248$. 


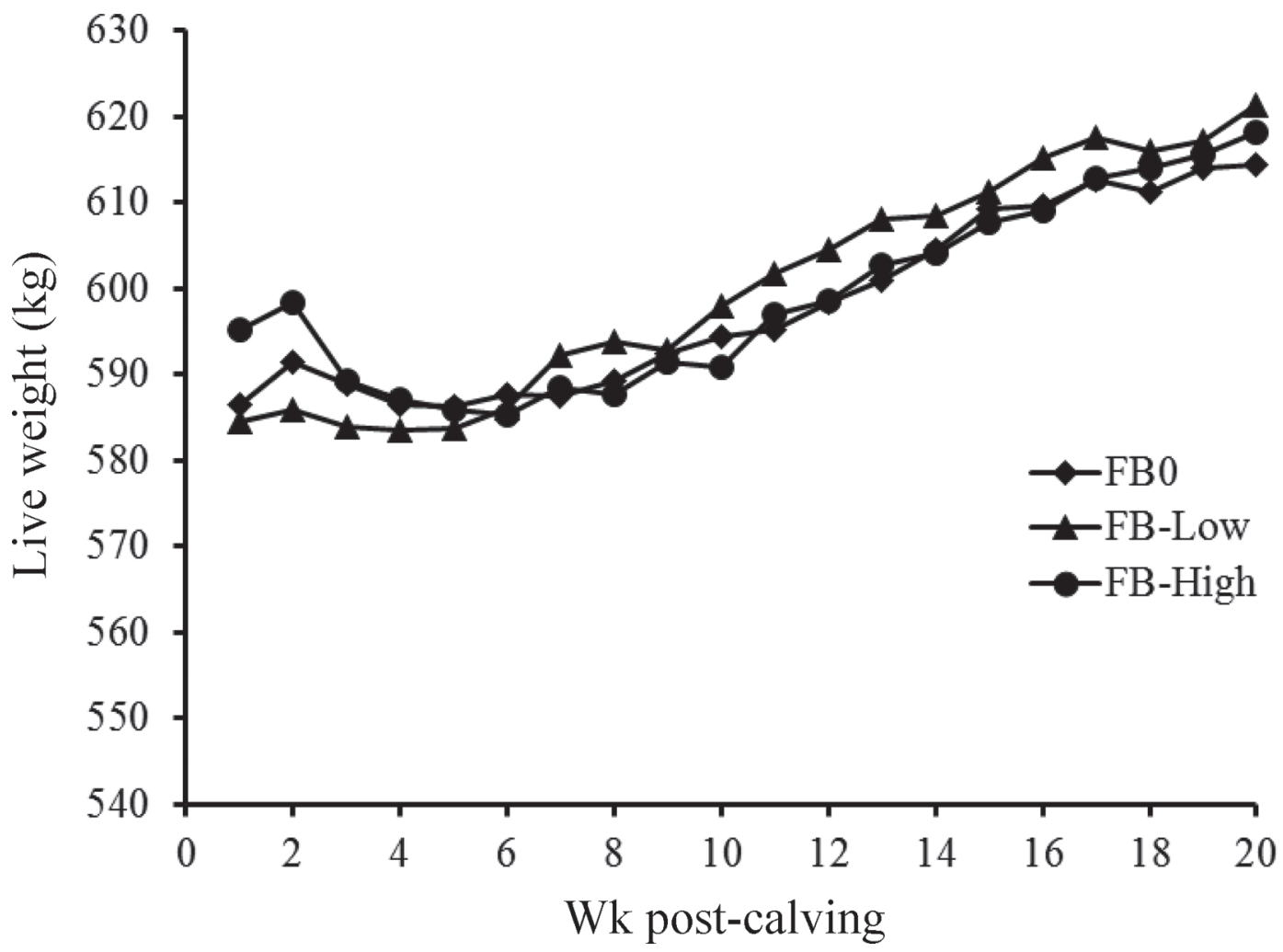

Figure 4. Body weight response of dairy cows to concentrates containing a range of field bean (FB) inclusion levels (FB0, FB-Low, or FBHigh) over the first $20 \mathrm{wk}$ of lactation. SEM $=8.0$; treatment $P=0.899$; time $P<0.001$; treatment $\times$ time $P=0.760$.

reduction in milk protein content and milk protein yield that they observed.

In the current study, FB replaced or partially replaced both maize starch (less degradable than FB starch) and wheat starch (more degradable than FB starch) in the concentrate (Offner et al., 2003), likely affecting rumen fermentation patterns and the associated reduction in milk fat content with the FB-High treatment. This reduction was in contrast to most previous studies; we propose that with the FB-High treatment, a reduction in rumen acetate production occurred due to the higher-concentrate starch and slightly lower fiber content, and this may have contributed to a reduction in de novo synthesis of milk fat. Possible adverse effects of diet on rumen function are supported in part by the lower ADF digestibility observed with this treatment. In addition, we postulate that altered rumen fermentation and biohydrogenation pathways, leading to inhibition of mammary lipid synthesis by specific fatty acid intermediates, as proposed by Bauman and Griinari (2001) and reviewed more recently by others (e.g., Harvatine et al., 2009), may also have contributed to this reduction. In addition, some evidence suggests that dietary methionine promotes milk fat synthesis (Hao et al., 2018), and, as such, the likely deficit of me- thionine in the FB diets in the present study may have contributed to the reduction in milk fat concentrations.

Effects of FB inclusion on the fatty acid profile of milk do not appear to have been examined previously; we found that FB inclusion in the current study increased the degree of saturation of the milk produced. This appears to have been largely driven by increasing concentrations of C16:0 in milk, with FB particularly high in C16:0 fatty acids (Grela and Gunter, 1995), with Moate et al. (2008) estimating that $42 \%$ of C16:0 is derived directly from the diet. Similarly, decreasing concentrations of $\mathrm{C} 18: 1$ with $\mathrm{FB}$ inclusion may reflect the higher concentration of C18:1 in soybean compared with FB (Grela and Gunter, 1995).

It is possible that the reduction in cow performance observed with FB inclusion could be avoided by supplementing the diet with specific limiting amino acids. Nevertheless, cow performance data need to be considered within the context of the total diet $\mathrm{CP}$ in the study $(180 \mathrm{~g} / \mathrm{kg}$ of DM), a level not unusual with earlylactation dairy cows offered grass silage-based diets in the United Kingdom and Ireland due to the often variable composition of grass silage on offer. However, it is possible that greater differences between treatments might have been observed with lower-protein diets as, 
(a)

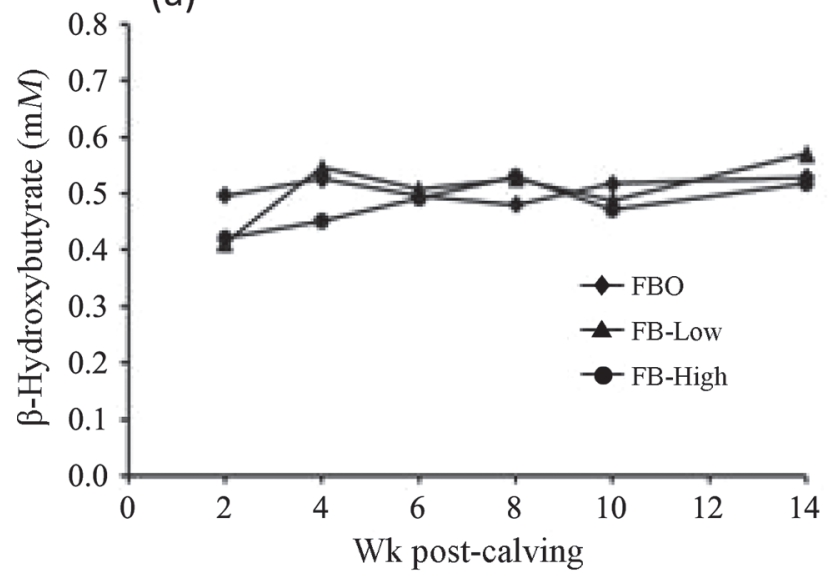

(c)

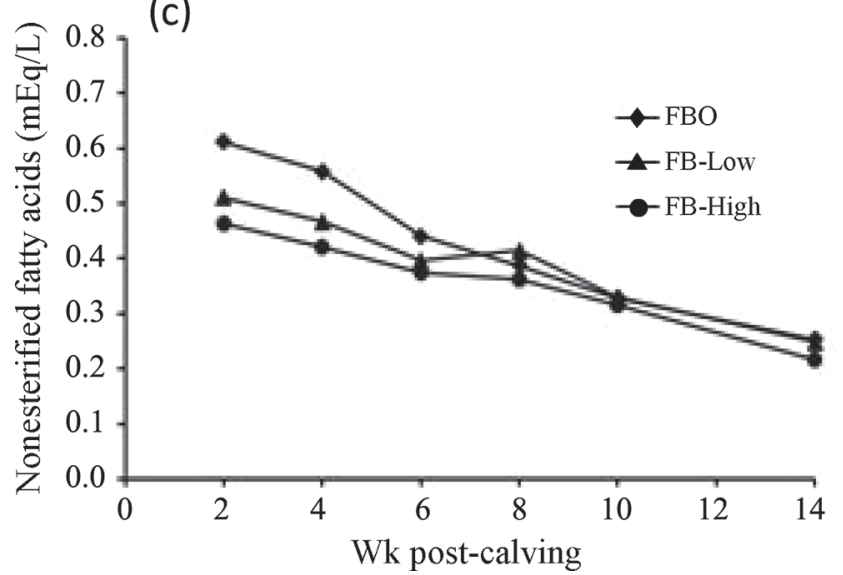

(b)

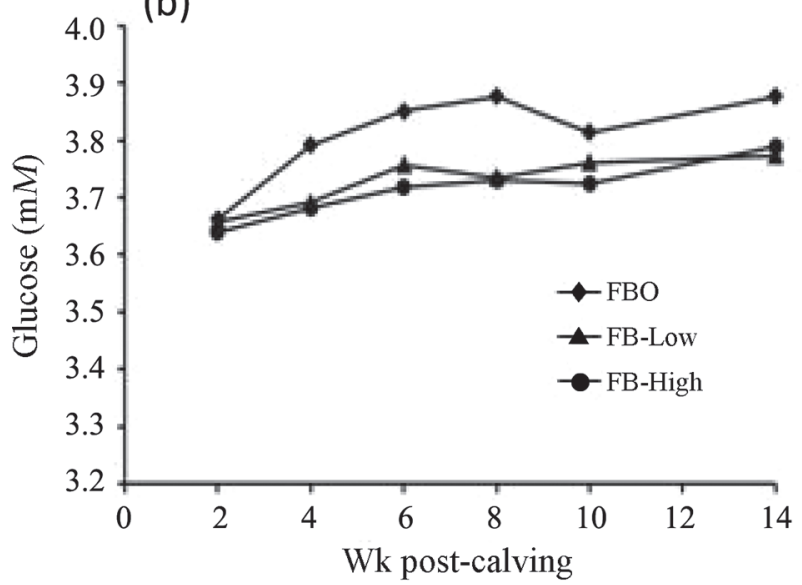

(d)

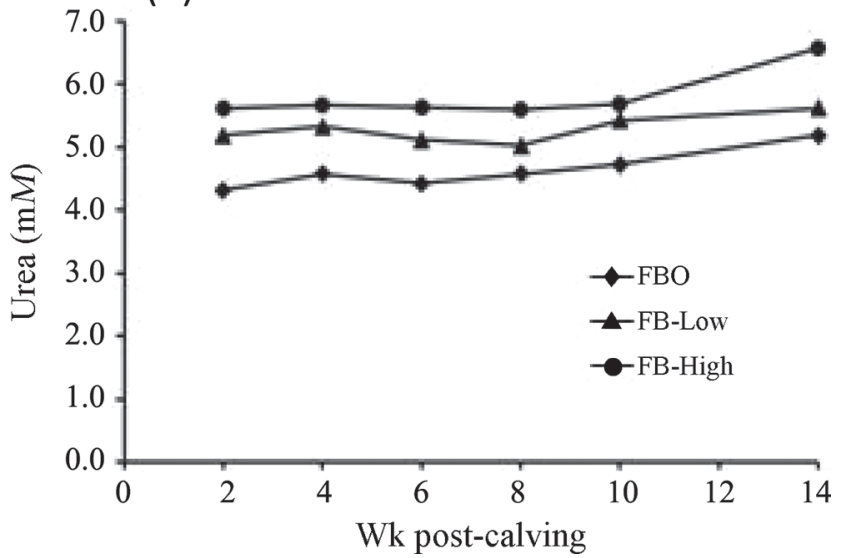

Figure 5. Effect of field bean (FB) inclusion level in the diet (FB0, FB-Low, or FB-High) on plasma chemical concentrations among dairy cows. (a) $\beta$-Hydroxybutyrate: SEM $=0.018$; treatment $P=0.419$; time $P=0.002$; treatment $\times$ time $P=0123$. (b) Glucose: SEM $=0.036$ : treatment $P=0.153$; time $P=0.010$; treatment $\times$ time $P=0.954$. (c) Nonesterified fatty acids: SEM $=0.020$; treatment $P=0.022$; time $P<$ 0.001 ; treatment $\times$ time $P=0.633$. (d) Urea: SEM $=0.103$; treatment $P<0.001$; time $P<0.001$; treatment $\times$ time $P=0.567$.

in general, responses to protein source and quality tend to be greater at lower diet protein levels. Nevertheless, Puhakka et al. (2016) observed no interaction between diet protein level (154 vs. $190 \mathrm{~g} / \mathrm{kg}$ of DM) and milk production when rapeseed meal was partially replaced with FB.

Table 5. Effects of field bean (FB) inclusion level in dairy cow concentrates on DMI, milk yield, and total ration digestibility coefficients

\begin{tabular}{|c|c|c|c|c|c|c|}
\hline Item & \multicolumn{3}{|c|}{ Treatment } & SEM & \multicolumn{2}{|c|}{$P$-value } \\
\hline Total DMI (kg/d) & 21.2 & 23.4 & 20.7 & 1.73 & 0.537 & 0.830 \\
\hline \multicolumn{7}{|c|}{ Digestibility coefficients (g/g) } \\
\hline $\mathrm{DM}$ & 0.784 & 0.775 & 0.771 & 0.0094 & 0.609 & 0.341 \\
\hline $\mathrm{OM}$ & 0.800 & 0.791 & 0.787 & 0.0098 & 0.602 & 0.339 \\
\hline $\mathrm{ADF}$ & $0.732^{\mathrm{a}}$ & $0.671^{\mathrm{ab}}$ & $0.644^{\mathrm{b}}$ & 0.0286 & 0.035 & 0.013 \\
\hline $\mathrm{NDF}$ & 0.699 & 0.659 & 0.666 & 0.0273 & 0.340 & 0.256 \\
\hline
\end{tabular}

\footnotetext{
${ }^{\mathrm{a}, \mathrm{b}}$ Means with the same superscript within a row do not differ significantly $(P>0.05)$.
} 
Table 6. Effect of field bean (FB) inclusion level in dairy cow concentrates on nitrogen utilization parameters

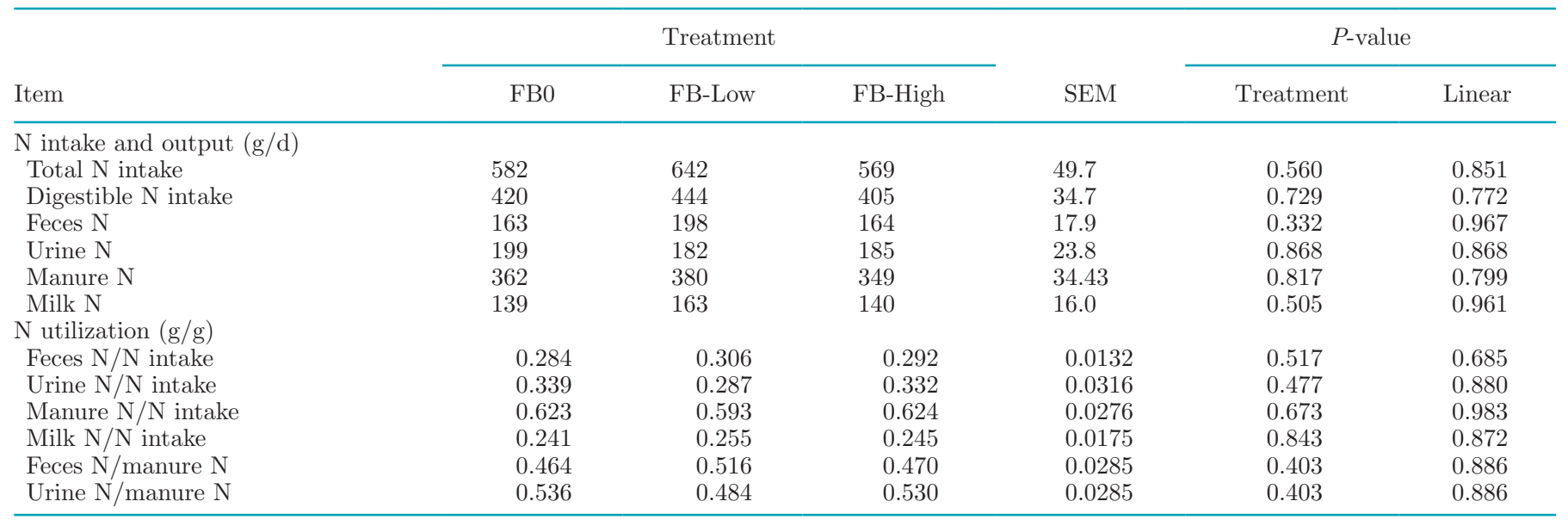

\section{Nutrient Utilization}

Field beans contain several antinutritional substances, some of which are known to have negative effects on rumen function and digestion ability (Newton and Hill, 1983; Dixon and Hosking, 1992). For example, the FB variety Fuego is a colored-flower variety, which is known to be a tannin-containing type. However, fecal scores - a simple proxy for rumen function - were unaffected by treatment in this study. In addition, with the exception of ADF, no digestibility coefficients for the other parameters examined were affected by FB inclusion. In our previously published work, we found fiber digestibility to be unaffected with an FB intake similar to that used with the FB-Low treatment (Johnston et al., 2019), but the reduction in ADF digestibility with the highest FB treatment in the current study is similar to the reduction in NDF digestibility observed by Puhakka et al. (2016). Puhakka et al. (2016) attributed this to the readily fermentable FB carbohydrate and

Table 7. Effects of field bean (FB) inclusion level in dairy cow concentrates on energy utilization parameters and methane production

\begin{tabular}{|c|c|c|c|c|c|c|}
\hline \multirow[b]{2}{*}{ Item $^{1}$} & \multicolumn{3}{|c|}{ Treatment } & \multirow[b]{2}{*}{ SEM } & \multicolumn{2}{|c|}{$P$-value } \\
\hline & FB0 & FB-Low & FB-High & & Treatment & Linear \\
\hline \multicolumn{7}{|c|}{ Energy intake and output (MJ/d) } \\
\hline GE intake & 392 & 425 & 375 & 31.7 & 0.548 & 0.719 \\
\hline Fecal energy & 87 & 99 & 88 & 8.1 & 0.542 & 0.885 \\
\hline DE intake & 305 & 327 & 287 & 24.6 & 0.546 & 0.610 \\
\hline Methane energy & 28 & 29 & 30 & 3.0 & 0.890 & 0.641 \\
\hline Urinary energy & 13 & 13 & 13 & 1.0 & 0.889 & 0.921 \\
\hline Milk energy & 102 & 105 & 102 & 9.6 & 0.964 & 0.994 \\
\hline ME intake & 264 & 284 & 243 & 21.4 & 0.446 & 0.513 \\
\hline Heat production & 151 & 158 & 165 & 15.1 & 0.803 & 0.519 \\
\hline Retained energy & 11 & 21 & -23 & 18.0 & 0.240 & 0.204 \\
\hline \multicolumn{7}{|c|}{ Energy utilization (MJ/MJ) } \\
\hline $\mathrm{DE} / \mathrm{GE}$ & 0.770 & 0.768 & 0.765 & 0.0092 & 0.518 & 0.292 \\
\hline $\mathrm{ME} / \mathrm{GE}$ & 0.675 & 0.667 & 0.650 & 0.0088 & 0.169 & 0.071 \\
\hline Heat production/ME & 0.564 & 0.573 & 0.679 & 0.0495 & 0.243 & 0.136 \\
\hline Milk energy/ME & 0.384 & 0.372 & 0.419 & 0.0171 & 0.188 & 0.182 \\
\hline Retained energy/ME & 0.052 & 0.055 & -0.097 & 0.0621 & 0.195 & 0.123 \\
\hline \multicolumn{7}{|l|}{$\mathrm{CH}_{4}$ production } \\
\hline $\mathrm{CH}_{4}(\mathrm{~g} / \mathrm{d})$ & 512 & 527 & 549 & 54.4 & 0.890 & 0.641 \\
\hline \multicolumn{7}{|c|}{$\mathrm{CH}_{4} /$ feed intake or milk yield $(\mathrm{g} / \mathrm{kg})$} \\
\hline $\mathrm{CH}_{4} / \mathrm{DMI}$ & 23.8 & 22.8 & 26.4 & 1.51 & 0.270 & 0.258 \\
\hline $\mathrm{CH}_{4} / \mathrm{OM}$ intake & 25.7 & 24.5 & 28.4 & 1.63 & 0.281 & 0.274 \\
\hline $\mathrm{CH}_{4} /$ milk yield & 16.8 & 17.2 & 17.8 & 1.21 & 0.850 & 0.850 \\
\hline $\mathrm{CH}_{4} / \mathrm{ECM}$ yield & 15.5 & 15.6 & 16.7 & 0.823 & 0.506 & 0.298 \\
\hline \multicolumn{7}{|c|}{$\mathrm{CH}_{4}$-E/energy intake (MJ/MJ) } \\
\hline $\mathrm{CH}_{4}-\mathrm{E} / \mathrm{GE}$ intake & 0.071 & 0.069 & 0.081 & 0.0067 & 0.241 & 0.205 \\
\hline $\mathrm{CH}_{4}-\mathrm{E} / \mathrm{ME}$ intake & 0.106 & 0.104 & 0.124 & 0.0103 & 0.150 & 0.113 \\
\hline
\end{tabular}

${ }^{1} \mathrm{GE}=$ gross energy; $\mathrm{DE}=$ digestible energy; $\mathrm{CH}_{4}-\mathrm{E}=$ methane energy. 


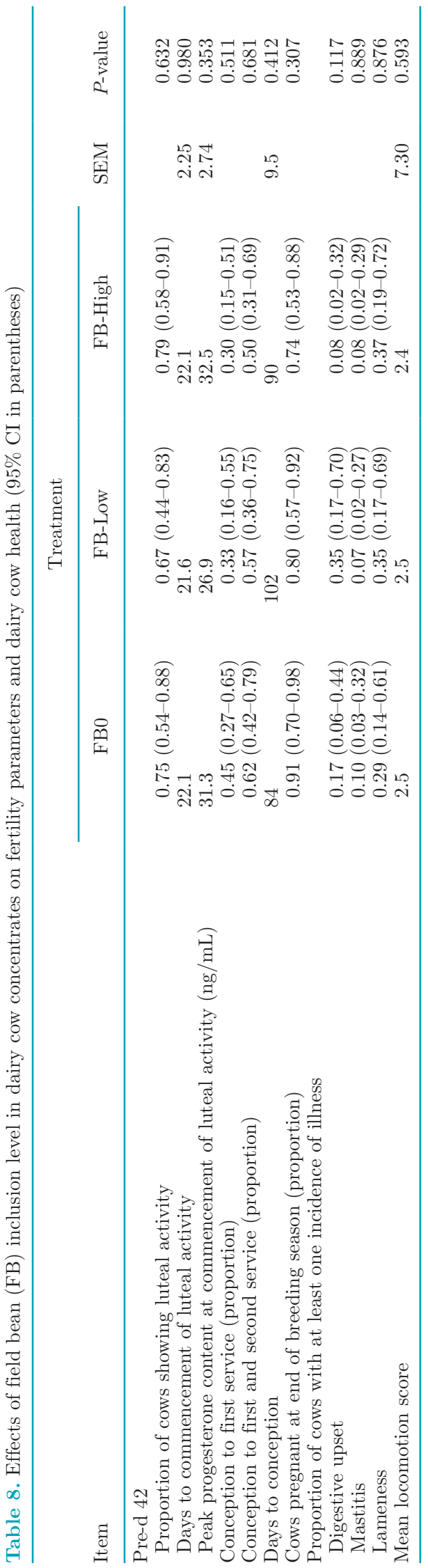

associated fermentation products, decreasing rumen $\mathrm{pH}$ and having a negative effect on cellulolytic bacteria activity, rather than to the presence of antinutritional factors. Puhakka et al. (2016) also found the apparent digestibility of $\mathrm{DM}, \mathrm{OM}, \mathrm{N}$, and starch to increase with FB inclusion, but they attributed this to the lower proportion of silage in the diets of cows offered FB, rather than to FB inclusion per se. Thus it appears that any effects of FB inclusion on digestibility are likely to be caused by other dietary factors, rather than by the presence of antinutritional factors. This is supported by the findings of Melicharová et al. (2009), who found cow performance to be unaffected when $\mathrm{FB}$ varieties containing either high or low levels of ANF were offered.

Although our earlier work (Johnston et al., 2019) indicated a reduction in the ratio of milk $\mathrm{N}$ to $\mathrm{N}$ intake with FB inclusion, a similar effect was not observed in the nutrient utilization portion of the current study, in agreement with other previous findings (Puhakka et al., 2016; Ramin et al., 2017). Nevertheless, the nutrient utilization phase in the current study involved only 4 cows per treatment and was undertaken at the end of the 20 -wk feeding study. When $\mathrm{N}$ use efficiency over the entire study period is examined using treatment mean intake and milk production data (with milk $\mathrm{N}$ calculated as milk protein/6.38), the ratio of milk $\mathrm{N}$ to $\mathrm{N}$ intake was $0.30,0.28$, and 0.27 for FB-0, FB-Low, and FB-High, respectively. The decreasing $\mathrm{N}$ use efficiency with increasing FB inclusion levels was reflected in an increase in plasma urea $\mathrm{N}$ levels, in agreement with Volpelli et al. (2012), the trend $(P=0.078)$ observed in our previous work (Johnston et al., 2019), and the increase in milk urea concentrations observed by $\mathrm{Pu}-$ hakka et al. (2016) when the rapeseed component of the diet was replaced by FB. In contrast, other studies (Comellini et al., 2009; Volpelli et al., 2010; Tufarelli et al., 2012) have found both blood and milk urea N concentrations to be either reduced or unchanged with FB inclusion. Protein in FB has a higher degradability in the rumen compared with protein from soybean meal or rapeseed meal (Ewing, 1997), and in general blood and milk urea levels increase when FB replaces a lessdegradable protein source.

None of the energy utilization parameters examined were affected by FB inclusion level, which was largely in agreement with our earlier study (Johnston et al., 2019), except that these latter authors inexplicably found a quadratic effect of FB inclusion on urine E output. Similarly, none of the $\mathrm{CH}_{4}$ production parameters examined were affected by FB inclusion, in agreement with previous indications (Johnston et al., 2019). However, Ramin et al. (2017) found that ratios of $\mathrm{CH}_{4}$ to DMI and $\mathrm{CH}_{4}$ to ECM were unaffected when rapeseed 
meal was replaced by $\mathrm{FB}$, whereas total $\mathrm{CH}_{4}$ production tended to be reduced, which they attributed in part to the higher fat content of rapeseed meal. Despite evidence suggesting that $\mathrm{CH}_{4}$ production may be reduced when ruminants are offered legume forages (Lüscher et al., 2014), there appears to be little evidence that this is the case with grain legumes, in line with the findings of the current study. Our results demonstrate enteric $\mathrm{CH}_{4}$ emissions to be unaffected by $\mathrm{FB}$ inclusion, but the effects of replacing imported protein ingredients with locally grown FB, across the life cycle of milk, needs to be examined.

\section{Fertility and Health}

Negative energy balance can have a detrimental effect on reproductive performance (Beam and Butler, 1999; Butler, 2003), but BCS and BW data in the current study suggest that energy balance differed little between treatments. However, the presence of phytoestrogens in many legumes species (for example, daidzein and genistein; Kaufman et al., 1997), including some FB cultivars, is often highlighted as a cause for concern in relation to dairy cow fertility. Phytoestrogens, compounds that are produced naturally in many plant species, may have adverse effects on ovarian function, including possibly inhibited luteinizing hormone surge, altered development of or lack of dominant follicles, abnormal follicular waves, early embryonic death, and repeat breeding (Mostrom and Evans, 2018). Although these compounds have been shown to suppress the secretion of luteinizing hormone (Zdunczyk et al., 2005) and to lower progesterone concentrations (Piotrowska et al., 2006), neither the time to onset of cyclicity, the proportion of cows cycling within $42 \mathrm{~d}$ of calving, nor the peak progesterone concentrations during the first estrus cycle were affected by diet in the present study. While actual conception rates within the study must be considered within the context of the number of cows on the study, we found no evidence that reproductive outcomes were affected by FB inclusion level. Vaginal mucus scores, assessed as an indicator of immune status, did not differ across treatments, suggesting that FB treatment has no effect on immune status. In addition, none of the health parameters examined were affected by FB inclusion in the diet, which again suggests that immune function was unaffected by treatment.

\section{CONCLUSIONS}

Including FB (Vicia faba. var. Fuego) in dairy cow diets at up to $8.4 \mathrm{~kg} / \mathrm{cow}$ per day had no detrimental effects on feed intake, milk production, body tissue reserves, fertility performance, cow health, or diet di- gestibility. The reduction in milk fat content with the highest FB treatment was likely due to the effect on rumen function of the high starch levels with this treatment, and the reduction in milk protein levels with FB inclusion was likely due to a deficit in specific limiting amino acids. Methane production was unaffected by FB inclusion.

\section{ACKNOWLEDGMENTS}

This study was funded by the Department of Agriculture, Environment, and Rural Affairs (DAERA) in Belfast, Northern Ireland, and by AgriSearch, Innovation Centre, Hillsborough, Northern Ireland. David Johnston was in receipt of a DAERA Postgraduate Studentship. The authors thank the staff of the Dairy Unit at the Agri-Food and Biosciences Institute (Hillsborough, Northern Ireland) for management of the experimental animals, and the laboratory staff for analysis of samples. The invaluable help provided by Jim Uprichard (Trouw Nutrition, Belfast, UK) in formulating the experimental concentrates was much appreciated.

\section{REFERENCES}

Abdulla, J. M. 2017. The use of field beans as a feed for broiler chickens. PhD Thesis. Harper Adams University, UK.

Bauman, D. E., and J. M. Griinari. 2001. Regulation and nutritional manipulation of milk fat: Low milk fat syndrome. Livest. Prod. Sci. 70:15-29. https://doi.org/10.1016/S0301-6226(01)00195-6.

Beam, S. W., and W. R. Butler. 1999. Effects of energy balance on follicular development and first ovulation in postpartum dairy cows. J. Reprod. Fertil. Suppl. 54:411-424.

Bligh, E. G., and W. J. Dyer. 1959. A rapid method of total lipid extraction and purification. Can. J. Biochem. Physiol. 37:911-917. https://doi.org/10.1139/o59-099.

Butler, W. R. 2003. Energy balance relationships with follicular development, ovulation and fertility in postpartum dairy cows. Livest. Prod. Sci. 83:211-218. https://doi.org/10.1016/S0301 $-6226(03) 00112-X$.

Comellini, M., L. Antonella Volpelli, D. Pietro Lo Fiego, and R. Scipioni. 2009. Faba bean in dairy cow diet: Effect on milk production and quality. Ital. J. Anim. Sci. 8:396-398. https://doi.org/10 .4081/ijas.2009.s2.396.

Dixon, R. M., and B. J. Hosking. 1992. Nutritional value of grain legumes for ruminants. Nutr. Res. Rev. 5(Suppl. 1):19-43. https:// doi.org/10.1079/NRR19920005.

Dvořák, R., A. Pechová, L. Pavlata, B. Klejdus, K. Kovařč́k, J. Dostálová, J. Culková, J. Filípek, E. Svajdlenka, and V. Capkova. 2006. Reduction in the content of antinutritional substances in Fava beans (Vicia faba) by different treatments. Slov. Vet. Zb. 43(Suppl. 10):174-179.

Edmonson, A. J., I. J. Lean, L. D. Weaver, T. Farver, and G. Webster. 1989. A body condition scoring chart for Holstein dairy cows. J. Dairy Sci. 72:68-78. https://doi.org/10.3168/jds.S0022 -0302(89)79081-0.

Ewing, W. N. 1997. The Feeds Directory, Volume 1: Commodity Products Guide. Context Publications, Leicestershire, UK.

Flores, F., M. Hybl, J. C. Knudsen, P. Marget, F. Muel, S. Nadal, L. Narits, B. Raffiot, O. Sass, I. Solis, and J. Winkler. 2013. Adaptation of spring faba bean types across European climates. Field Crops Res. 145:1-9. https://doi.org/10.1016/j.fcr.2013.01.022. 
Grela, E. R., and K. D. Gunter. 1995. Fatty acid composition and tocopherol content of some legume seeds. Anim. Feed Sci. Technol. 52:325-331. https://doi.org/10.1016/0377-8401(94)00733-P.

Qi, H., C. Meng, X. Jin, X. Li, P. Li, and X. Gao. 2018. Methionine promotes milk protein and fat synthesis and cell proliferation via the SNAT2-P13K signaling pathway in bovine mammary epithelial cells. J. Agric. Food Chem. 66:11027-11033. https://doi.org/ 10.1021/acs.jafc.8b04241.

Harvatine, K. J., Y. R. Boisclaire, and D. E. Bauman. 2009. Recent advances in the regulation of milk fat synthesis. Animal 3:40-54. https://doi.org/10.1017/S1751731108003133.

Hutson, G. D., and S. van Mourik. 1981. Food preferences of sheep. Aust. J. Exp. Agric. 21:575-582. https://doi.org/10.1071/ EA9810575.

Ingalls, J., and J. McKirdy. 1974. Faba bean as a substitute for soybean meal or rapeseed meal in rations for lactating cows. Can. J. Anim. Sci. 54:87-89. https://doi.org/10.4141/cjas74-013.

Ireland-Perry, R. L., and C. C. Stallings. 1993. Fecal consistency as related to dietary composition in lactating Holstein cows. J. Dairy Sci. 76:1074-1082. https://doi.org/10.3168/jds.S0022 -0302(93)77436-6.

Johnston, D. J., K. Theodoridou, and C. P. Ferris. 2019. The impact of field bean inclusion level in dairy cow diets on cow performance and nutrient utilisation. Livest. Sci. 220:166-172. https://doi.org/ 10.1016/j.livsci.2018.12.015.

Kaufman, P. B., J. A. Duke, H. Brielmann, J. Boik, and J. E. Hoyt. 1997. A comparative survey of leguminous plants as sources of the isoflavones, genistein and daidzein: Implications for human nutrition and health. J. Altern. Complement. Med. 3:7-12. https://doi .org/10.1089/acm.1997.3.7.

Kudlinskienè, I., J. Lionikienè, J. Klementavičiūtè, G. Stanytė, R. Gružauskas, R. Stankevičius, D. Urbšienè, S. Bliznikas, A. Racevičiūtè-Stupelienè, M. Ots, and M. Kass. 2018. Effect of extruded field beans "Fuego" (Vicia Faba) on dairy cow's performance and milk sensory properties. Vet Med Zoot. T. 76 (98) Supplement.

Licitra, G., T. M. Hernandez, and P. J. Van Soest. 1996. Standardization of procedures for nitrogen fractionation of ruminant feeds. Anim. Feed Sci. Technol. 57:347-358. https://doi.org/10.1016/ 0377-8401(95)00837-3.

Little, M. W., N. E. O'Connell, M. D. Welsh, F. J. Mulligan, and C. P. Ferris. 2017. Concentrate supplementation of a diet based on medium-quality grass silage for 4 weeks prepartum: Effects on cow performance, health, metabolic status, and immune function. J. Dairy Sci. 100:4457-4474. https://doi.org/10.3168/jds.2016-11806.

Lüscher, A., L. Mueller-Harvey, J. F. Soussana, R. M. Rees, and J. L. Peyraud. 2014. Potential of legume-based grassland-livestock systems in Europe: A review. Grass Forage Sci. 69:206-228. https: //doi.org/10.1111/gfs.12124.

Melicharová, V., A. Pechová, R. Dvořák, and L. Pavlata. 2009. Performance and metabolism of dairy cows fed bean seeds (Vicia faba) with different levels of anti-nutritional substances. Acta Vet. Brno 78:57-66. https://doi.org/10.2754/avb200978010057.

Moate, P. J., W. Chalupa, R. C. Boston, and I. J. Lean. 2008. Milk fatty acids II: Prediction of the production of individual fatty acids in bovine milk. J. Dairy Sci. 91:1175-1188. https://doi.org/10 $.3168 /$ jds.2007-0226.

Mordenti, A., F. Merendi, M. Fustini, and A. Formigoni. 2007. Effects of different protein plants in cows diet on milk for Parmigiano Reggiano production. Ital. J. Anim. Sci. 6:463-465. https://doi.org/10 .4081/ijas.2007.1s.463.

Mostrom, M., and T. J. Evans. 2018. Phytoestrogens. Pages 817-833 in Veterinary Toxicology: Basic and Clinical Principles. 3rd ed. R.
C. Gupta, ed. Academic Press, Cambridge, MA. https://doi.org/ 10.1016/B978-0-12-811410-0.00060-X

Newton, S. D., and G. D. Hill. 1983. The composition and nutritive value of field beans. Nutr. Abstr. Rev. Series B. 53:99-115.

Offner, A., A. Bach, and D. Sauvant. 2003. Quantitative review of in situ starch degradation in the rumen. Anim. Feed Sci. Technol. 106:81-93. https://doi.org/10.1016/S0377-8401(03)00038-5.

Park, R. S., R. E. Agnew, F. J. Gordon, and R. W. J. Steen. 1998. The use of near infrared reflectance spectroscopy (NIRS) on undried samples of grass silage to predict chemical composition and digestibility parameters. Anim. Feed Sci. Technol. 72:155-167. https:// doi.org/10.1016/S0377-8401(97)00175-2.

Piotrowska, K. K., L. Woclawek-Potocka, M. M. Bah, M. K. Piskula, W. Pilawski, A. Bober, and D. J. Skarzynski. 2006. Phytoestrogens and their metabolites inhibit the sensitivity of the bovine corpus luteum to luteotropic factors. J. Reprod. Dev. 52:33-41. https://doi.org/10.1262/jrd.17054.

Puhakka, L., S. Jaakkola, L. Simpura, T. Kokkonen, and A. Vanhatalo. 2016. Effects of replacing rapeseed meal with fava bean at 2 concentrate crude protein levels on feed intake, nutrient digestion, and milk production in cows fed grass silage-based diets. J. Dairy Sci. 99:7993-8006. https://doi.org/10.3168/jds.2016-10925.

Purcell, P. J., R. A. Law, A. W. Gordon, S. A. McGettrick, and C. P. Ferris. 2016. Effect of concentrate feeding method on the performance of dairy cows in early to mid lactation. J. Dairy Sci. 99:2811-2824. https://doi.org/10.3168/jds.2015-9988.

Ramin, M., A. Höjer, F. Fogelberg, and M. Hetta. 2017. The effects of legume seeds on the lactation performance of dairy cow fed grass silage-based diets. Agric. Food Sci. 26:129-137. https://doi.org/10 $.23986 /$ afsci.64417.

Schwab, C. G., L. D. Satter, and B. Clay. 1976. Response of lactating dairy cows to abomasal infusion of amino acids. J. Dairy Sci 59:1254-1270. https://doi.org/10.3168/jds.S0022-0302(76)84354 -8 .

Thomas, C. 2004. Feed into Milk: A New Applied Feeding System for Dairy Cows. Nottingham University Press, Nottingham, UK.

Tufarelli, V., R. U. Khan, and V. Laudadio. 2012. Evaluating the suitability of field beans as a substitute for soybean meal in early lactating dairy cow: Production and metabolic responses. Anim. Sci J. 83:136-140. https://doi.org/10.1111/j.1740-0929.2011.00934.x.

Volpelli, L. A., M. Comellini, M. Gozzi, F. Masoero, and M. Moschini 2012. Pea (Pisum sativum) and faba beans (Vicia faba) in dairy cow diet: Effect on milk production and quality. Ital. J. Anim. Sci. 11:217-222. https://doi.org/10.4081/ijas.2012.e40.

Volpelli, L. A., M. Comellini, F. Masoero, M. Moschini, D. P. L. Fiego, and R. Scipioni. 2010. Faba beans (Vicia faba) in dairy cow diet: Effect on milk production and quality. Ital. J. Anim. Sci. 9:138 144. https://doi.org/10.4081/ijas.2010.e27.

Watson, C., M. Reckling, S. Preissel, J. Bachinger, G. Bergkvist, T. Kuhlman, K. Lindstrom, T. Nemecek, C. F. E. Topp, A. Vanhatalo, P. Zander, D. Murphy-Bokern, and F. L. Stoddard. 2017. Grain legume production and use in European agricultural systems. Adv. Agron. 144:235-303. https://doi.org/10.1016/bs.agron 2017.03.003.

Wilkins, R. J., and R. Jones. 2000. Alternative home-grown protein sources for ruminants in the United Kingdom. Anim. Feed Sci. Technol. 85:23-32. https://doi.org/10.1016/S0377-8401(00)00140 -1 .

Zdunczyk, S., M. Piskula, T. Janowski, W. Baranski, and M. Ras. 2005. Concentrations of isoflavones in blood plasma of dairy cows with different incidence of silent heat. Bull. Vet. Inst. Pulawy 49:189-191. 